Article

\title{
Corporate Bankruptcy Prediction Model, a Special Focus on Listed Companies in Kenya
}

\author{
Daniel Ogachi ${ }^{1, * \mathbb{C}}$, Richard Ndege ${ }^{2}$, Peter Gaturu ${ }^{3}$ and Zeman Zoltan ${ }^{1}$ \\ 1 Department of Finance, Szent Istvan University, 2100 Gödöllő, Hungary; zeman.zoltan@gtk.szie.hu \\ 2 Twenty Four Secure Security Services, Nairobi 50353-00100, Kenya; marisandege@gmail.com \\ 3 BSS Department, Jomo Kenyatta University of Agriculture and Technology, Karen 62000-00200, Nairobi, \\ Kenya; pmgaturu@gmail.com \\ * Correspondence: ogachdniel@gmail.com; Tel.: +36-3088-23119
}

Received: 23 January 2020; Accepted: 26 February 2020; Published: 4 March 2020

\begin{abstract}
Predicting bankruptcy of companies has been a hot subject of focus for many economists. The rationale for developing and predicting the financial distress of a company is to develop a predictive model used to forecast the financial condition of a company by combining several econometric variables of interest to the researcher. The study sought to introduce deep learning models for corporate bankruptcy forecasting using textual disclosures. The study constructed a comprehensive study model for predicting bankruptcy based on listed companies in Kenya. The study population included all 64 listed companies in the Nairobi Securities Exchange for ten years. Logistic analysis was used in building a model for predicting the financial distress of a company. The findings revealed that asset turnover, total asset, and working capital ratio had positive coefficients. On the other hand, inventory turnover, debt-equity ratio, debtors turnover, debt ratio, and current ratio had negative coefficients. The study concluded that inventory turnover, asset turnover, debt-equity ratio, debtors turnover, total asset, debt ratio, current ratio, and working capital ratio were the most significant ratios for predicting bankruptcy.
\end{abstract}

Keywords: bankruptcy; insolvency; financial distress; default; failure; forecasting methods

\section{Introduction}

Bankruptcy prediction is a technique of forecasting and projecting on company financial distress of both public and firms. The purpose of predicting bankruptcy is fundamental in assessing the financial condition of a company and prospects in its operations. Corporate bankruptcy prediction is a very crucial phenomenon in economics. The financial soundness of a company is of great importance to the various actors and participants of the business cycle. The participants and interested parties include the policymakers, investors, banks, internal management, and the general public referred to as consumers. Accurate prediction of the financial performance of companies is of great importance to various stakeholders in making important and significant decisions concerning their relationship and engagement with companies. Financial distress is a global phenomenon that affects companies across all sectors of the economy (Zhang et al. 2013).

Additionally, bankruptcy prediction is essential for investors as well as suppliers or retailers to the business. Credit lenders and investors need to evaluate the financial bankruptcy risk of a company before making an investment or credit-granting decisions to avoid a significant loss by banks and other credit lenders. A company's suppliers or retailers always conduct credit transactions with the company, and they also need to fully understand the company's financial status and make decisions on the credit transaction. To correctly predict a company's financial distress is of great concern to the various 
stakeholders of a company. Problems concerning bankruptcy have necessitated the need for studies to establish different stressors to companies to aid investors in making prudential investment decisions.

Corporate failures in significant economic companies have spurred research for better understanding to develop prediction capabilities that guide decision making in investments. Financial distress projections in companies are a product of available data from listed companies, public firms that have sunk. Available accounting ratios may be a vital indicator or signal to indicate danger. Typically, firms are quantified by many indicators that describe their business performance based on mathematical models constructed from past observations based on evidence from data.

Decisions of a corporate borrower on credit risk traditionally were exclusively based upon subjective judgments made by human experts, based on past experiences and some guiding principles. However, two significant problems associated with this approach include the difficulty to make consistent estimates and the fact that it tends to be reactive rather than predictive (Cleofas-Sánchez et al. 2016).

Bankruptcy prediction is of great importance to all participants in the insurance market, including insurance regulators, policyholders, agents, and insurance companies. As insurance products become more and more familiar to the public, they strengthen the consumers' willingness to buy products. However, as the service period of insurance products happens after the purchase of products, the consumer is very concerned when purchasing products of the insurance company about whether they will be able to pay in the future. Assessing the solvency of an insurance company in the future during the product service period is very important to the policyholder's purchase decision, and equivalently crucial to the operation of the insurance company.

In many instances, policyholders have a habit of thinking that large companies are financially stable and that they are solvency guaranteed, which is not always the case. In assessing the creditworthiness of companies, the various actors use solvency adequacy ratio indicators. In most companies, the companies have a given solvency adequacy ratio used as a yardstick for measuring performance, which is required to be made public. One of the questions that stakeholders ask themselves is whether the indicator is reliable for policyholders to forecast the solvency of a company using the current information.

This article, therefore, attempts to evaluate different bankruptcy prediction models that have been used in different countries over time. Several studies have been conducted in Kenya concerning bankruptcy prediction, with most studies trying to validate the Altman's Z-score developed in 1968 in projecting for corporate bankruptcy. None of the studies came up with a model that applies to listed companies in Kenya to determine the financial viability to make investment decisions. This study sought to bring new knowledge in the field of financial economics by developing a current and operative model that can be able to be used by investors in making investment decisions in both private and public companies based on earnings management. Recent cases have seen several listed companies going under with investors' finances even after declaring huge annual dividends to shareholders. This research study sought to answer a number of research questions. What is the contribution of debt coverage ratios on bankruptcy prediction? How do liquidity management ratios affect the financial performance of listed companies? Lastly, how activity ratios contribute to corporate earnings management concerning financial performance? The study conducted a trend analysis using canonical correlation and logistical regression model to determine relationships among various variables.

The remainder of this paper is organized into five chapters. Section 2 of this paper discusses the empirical orientation of the study based on available literature from other scholars. Section 3 presents data and methods of analysis used in the study, while Section 4 gives a highlight of empirical results and discussions inline with past literature. The last section, Section 5 , provides conclusions deduced from the primary research findings. 


\section{Literature Review}

\subsection{Earnings Management and Bankruptcy Prediction}

Studies have examined the causes of business failure indicated by values of bankruptcy scores established during the decline stage of the business. In a survey of the 70 Estonian manufacturing firms, the researcher obtained the causes of bankruptcy from court judgments. The firms classified the reasons and the types of failure, that is, internal factors, that are different from management deficiencies and external factors to the firm. Ohlson's model and a local (Grünberg's) bankruptcy prediction model were used to calculate bankruptcy scores for the first and second pre-bankruptcy years. Applying median tests form independent samples to examine whether the different failure types are associated with different failure risk. The findings revealed that multiple causes have a significantly higher bankruptcy risk than single reasons for the year before the declaration of bankruptcy. The results indicate that numerous reasons lead to a considerably higher insolvency risk as compared with a single cause for the year before bankruptcy disclosure (Lukason and Hoffman 2014).

Altman's first bankruptcy prediction model has gained prominence and is at the epicentre of all economists and scientists all over the world. Early detection of a possible threat to the financial performance of a company is a critical phenomenon in the world of economic analysis.

Financial misery and business failure is usually an extremely costly and disruptive event. Statistics have been used to predict financial distress in an attempt to forecast the future of businesses. Popular approaches to discriminant analysis and logistic regression are used to predict bankruptcy. Using a variety of cost ratios, the results by (Gepp and Kumar 2015) in their study showed that decision trees and survival analysis models have good prediction accuracy, which justifies their use and supports further investigation.

In another study, the researcher analyzed the influence of financial distress on the investment behaviour of companies. The study included companies from Germany, Canada, Spain, France, Italy, the United Kingdom, and the USA. The researcher sought to use several institutions from different study environments. Using the generalized method of moments (GMM) system, from panel data, the results showed that the influence of financial distress on investment is distinct according to the investment opportunities available to companies. So, companies in difficulties with fewer opportunities have the highest propensity to underinvest, while firms in problems with better opportunities do not present different investment behaviour than healthy companies (López-Gutiérrez et al. 2015).

The dwindling in the profitability of listed companies not only intimidates the interests of the enterprise and internal workforce but also leads to significant financial losses to investors. Therefore companies must establish early predictive signs of financial difficulties in companies that will help in issues relating to corporate governance. A study on 107 listed companies in the Shanghai Stock Exchange and the Shenzhen Stock Exchange to develop the phenomenon of financial distress interviewed companies that received the label of special treatment between the years 2001 and 2008. Data mining techniques were used to build a model for establishing financial trouble in companies. One of the critical contributions of the paper was the discovery that return on total assets, earnings per share, the net profit margin of total assets, and cash flow per share play an essential role in the prediction of deterioration in profitability. Therefore, the study provided a suitable method for forecasting the financial distress of companies (Geng et al. 2015).

In Lithuania, where private limited companies dominate the country, a bankruptcy prediction model was built to assess the probability of bankruptcy in companies. The study used 73 already bankrupt and 72 still operating companies to deduce a bankruptcy prediction model to be used for predicting bankruptcy of business ventures. The study used the following analysis techniques: Mann-Whitney U test techniques, correlations, and multivariate discriminant analysis. The findings revealed that the model was $89 \%$ accurate in predicting for bankruptcy of private companies in Lithuania (Šlefendorfas 2016). 
In a study by (Laitinen and Suvas 2016), to establish the influence of Hofstede's original cultural dimensions on the prediction of financial distress, 1,255,768 non-failed and 22,594 failed yearly firm observations were obtained from 26 European countries. A model known as the logistic regression model was used to predict the future financial position of a company in an international context. The empirical findings revealed that Hofstede's dimensions significantly moderate the effects of economic predictors in failure prediction. However, the equity ratio, used as a solvency measure, and return on assets ratio (ROA), used to measure company success, play a vital role in bankruptcy prediction models, irrespective of the position of the moderating effects that they play at times. Solvency and profitability, therefore, are imperative forecasters of bankruptcy in international financial modelling. The contributions of regulating effects and further variables on the overall performance of prediction models are not resilient owing to the dominant role of the equity ratio across cultures.

For centuries, research in predicting bankruptcy has been very challenging. Models have been built from financial figures, stock market data, and specific firm variables-both low dimensional data and high on company managers and directors in the models of prediction. Relational models are found to have an improved prediction over financial models that are simple when detecting those firms that are riskier than others. Combining relational and economic data gives the most substantial performance increase (Tobback et al. 2017). Managers are expected to carefully build bankruptcy prediction models and adjust them to the size, type, and risk of the activities of the company (Boratyńska and Grzegorzewska 2018).

Most bankruptcy research seems to have relied on parametric models like multiple discriminant analysis and logit. The parametric models can only handle a finite number of predictors, which is the most significant limitation of the model. The gradient boosting model has been advocated thanks to its nature of accommodating for a vast amount of predictors that can be ranked in an orderly manner ranging from best to worst based on their predictive power. A study on 1115 U.S. bankruptcy filings and 91 predictor variables established that ownership structure/concentration and CEO compensation were treated as non-traditional reliable predictors, while unscaled market and accounting variables were treated as good predictors when studying firm size effects. Macro-economic variables, analyst forecasts, and industry variables were found to be the weakest predictors (Jones 2017).

Improving corporate financial risk management requires a dynamic financial distress prediction. Early researchers in constructing financial distress models ignored the time weight of samples. A study on dynamic financial distress prediction (DFDP) proposed two approaches based on time weighting and Adaboost support vector machine (SVM) ensemble, which are more suitable for DFDP in the case of financial distress concept drift (Sun et al. 2017).

Klepac and Hampel (2017) conducted a study on predicting financial distress of agriculture companies in the European Union. The survey interviewed 250 agriculture business companies, with 62 of them having defaulted in 2014. The findings revealed that increasing the distance to bankruptcy leads to a decrease in the average accuracy of the financial distress prediction. Therefore, there was a significant difference flanked by the active and distressed companies in terms of liquidity, rentability, and debt ratios.

A study was conducted in India, which is an emerging economy, to establish corporate distress prediction where bankruptcy details were not available. The study used firm-specific parameters to capture any signs of distress for the firms. The study used standard logistic and Bayesian modelling to predict distressed firms in the corporate sector of India. The study found out that the Bayesian methodology provides for a consistent predictive capability of identifying the early signal of failure in Indian companies (Shrivastava et al. 2018).

All over the world, several models have been designed to measure the insolvency of companies. Each model has several shortcomings during its application. One of the deficiencies facing models is the inability to transfer and apply one model from one country to the other because of the difference in the economic conditions among countries. A well-developed model in Hungary may not work well in another country; therefore, there is a recommendation to develop a predictive model that takes 
into account the specific conditions of a particular state using the real data on the financial situation (Svabova et al. 2018).

The literature suggests that firms with a higher prior history of affirmative corporate social responsibility (CSR) commitment are less likely to file for insolvency when they are financially distressed. However, they are expected to experience accelerated recovery from distress. Moral capital shrinks bankruptcy likelihood when the firm grows more massively. Additionally, capital mitigates bankruptcy likelihood when the firm relies on intangible assets to operate and when firms operate in a more litigious business environment (Lin and Dong 2018).

Financial ratios are essential in predicting the bankruptcy of business ventures. Various variables measure the financial soundness of an enterprise. In a study conducted in Indonesia on bank financial ratios, the researcher used the capital adequacy ratio (CAR), loan to deposit rate (LDR), non-performing loan (NPL), operating income operating costs (BOPO), return on assets (ROA), return on equity (ROE), and Net Interest Margin (NIM). Using logit regression with 40 banks, LDR had a significant effect on the profitability of banks in Indonesia. CAR, NPL, BOPO, ROE, and NIM had no considerable impact on bankruptcy.

Predicting bankruptcy has gained attention for almost a century now and remains one of the hottest topics of concern in economics. The financial distress prediction aims to design a model that blends the various economic variables to foresee the condition of the firm. Several methods proposed statistical modelling and artificial intelligence (Zięba et al. 2016). Textual disclosures introduce deep learning models for bankruptcy prediction. Mai et al. (2019) established that deep learning models yield superior forecasting on bankruptcy prediction. Blending textual data with ratio analysis can improve the prediction accuracy.

Most institutions and researchers have focused on bankruptcy prediction owing to the growth in the complexity of global economies and an increasing number of corporate failures ignited by the 2008 crisis. Fisher's linear discriminant has gained dominance and popularity in terms of accuracy (García et al. 2019).

Other bankruptcy predictor models of companies have been the convolutional neural network, which is applied to identify the bankruptcy vice in a variety of fields. Convolutional neural networks in financial analysis have been used to predict stock price movements. However, it is not a very commonly applied technique. Only very few studies have used it. The convolutional neural networks approach uses two methods of the balance sheet and the profit and loss account to test for bankruptcy. Hosaka (2019) established that predicting bankruptcy through trained networks is shown to have higher performance as compared with decision trees, intelligent machines, and linear discriminant analysis, which was according to a study they conducted in the Japanese Stock Markets using 102 delisted companies and 2062 financial statements of listed companies.

In another study to establish whether a sensitivity variable, industry beta, has a significant impact on the firm's likelihood of default, the study used logistic regression and multiple discriminant analysis on listed companies in India. The sensitivity variable for industry factors, industry beta, is found to be statistically significant in predicting defaults. Higher sensitivity to industry factors leads to an increased probability of default (Agrawal and Maheshwari 2019).

In another study to predict the financial distress companies in the trading and services sector in Malaysia, the researcher used using financial distress companies as the dependent variable and macroeconomic variables and financial ratios as the independent variables. Based on the results from a Logit analysis, the study established that turnover ratio, debt ratio, total assets, working capital ratio, net income to total assets ratio, and base lending rate are the independent variables used to predict financially distressed companies in the trading and services sector in Malaysia (Alifiah 2014).

Whether to use accounting- or market-based information to predict corporate default has been a long-standing research debate. Integrating a regime-switching mechanism, we establish a hybrid bankruptcy prediction model with various loadings on accounting- and market-based approaches to 
re-examine bankruptcy prediction. Recommendations include creditors to increase the loading on market-based information when large and liquid corporations are considered.

In the present states of the economy, there is an increasing number of organizations facing financial difficulties, which may, at times, lead to bankruptcy. The deficiencies of customary determining models inspire this examination. Partial least squares logistic regression allows for incorporating a large number of ratios into the model and also solves the problem of correlations taking into account the missing data in the matrix. The results obtained confirm the superiority of this method compared with conventional methods of projecting for bankruptcy because the model allows considering all the indicators in predicting financial distress (Ben Jabeur 2017).

\subsection{Emergent Bankruptcy Prediction Systems}

Banks frequently adopt expert systems in supporting their decisions when advancing credit. Machine learning techniques represent one type that has been used for decades in issuing loans. Banks use prudential choices of protecting the performance of companies by accessing corporate loan applicants. One of the methods they use is data envelopment analysis (DEA) to evaluate several decisions making units (DMU) ranked based on the best practice in their sector. Linear programming is imperative as it is used in calculating corporate efficiency, used as a measure of differentiating between financially sound companies and those that are economically distressed. The results based on a study that sampled 742 listed Chinese companies over ten years suggest that Malmquist DEA offers discernments into the competitive position of a company in addition to accurate financial distress predictions based on the DEA efficiency measures (Li et al. 2017).

Ratio analysis financial indicators are the most popular variables used in bankruptcy prediction models. They often exhibit heavily skewed results owing to the presence of outliers. It is not very clear how different approaches affect the predictive power of models that predict bankruptcy. One of the challenges faced in models is the lack of a clear cut way of how to handle outliers and extremes that affect the power of models - two ways of reducing outlier bias by omission and winsorization. The categorization of financial ratios is an effective way of handling outliers concerning the predictive performance of bankruptcy prediction models.

Predicting financial distress in empirical finance has received a lot of attention from researchers throughout the globe. Sampling small and medium enterprises in France using the Logit model, artificial neural networks, support vector machine techniques, partial least squares, and a hybrid model integrating support vector machine with partial least squares, it has been established that, within a year of financial distress, support vector machine should be preferred because it is the best and most accurate method for predicting for bankruptcy. In the case of two years, then the hybrid model outperforms the support vector machine, Logit model, partial least squares, and artificial neural networks with $94.28 \%$ overall accuracy of prediction. Financially distressed firms are found to be smaller, more leveraged, and with lower repayment capacity. In addition, they have lower profitability, liquidity, and solvency ratios. Creditors should, therefore, correctly evaluate the financial position of firms and be keen on any signs that may lead to negative growth to avoid capital loss and costs-related risks (Mselmi et al. 2017).

In the design of a monetary financial disaster prediction model, financial ratio selection and classifier design play the most critical roles. A methodology based totally on expert opinion, statistical concept, and computational intelligence method has been widely applied. In this study, a hybrid shape integrating a mathematical idea and computational talent technique were once developed using a genetic algorithm (GA) with statistical measurements and fuzzy useful judgment-based fitness features for essential ratio selection. In the experiments, two monetary ratio sets were used, one extracted from the recommendations of different research and the other from employing the use of the GA toolbox in the Statistical Analysis Software (SAS) program package. They have been utilized to take a look at the proposed ratio choice schemes. A distinction between the improved hybrid shape and different well-applied structures was also given. The experimental results of financial data based on less than a 
four-year period before bankruptcy occurrence were used to gauge the performance of the proposed prediction model (Chou et al. 2017).

Introduction to predictive bankruptcy is an objective and realistic problem facing companies and firms, and because of its frequency, it has discovered a specific niche in monetary and investment literature following the motto "prevention is better than cure". In this respect, more than a few fashions have been presented based totally on motives and motives for bankruptcy. Numerous research has been committed to discovering high-quality experimental techniques in predicting the economic crisis. As a result, exceptional patterns have been generated uniquely to predict the financial crisis. Prediction of financial disaster is significant for all corporations owing to the fact it has a profound effect on the economic system and raises expenses, inflicting many social problems. There are many strategies and methods through which companies and monetary analysts can predict bankruptcy. A combination of various ratios used for bankruptcy prediction and classification fashions can help to choose financial ratios and amplify prediction accuracy.

Neural networks are one of the numerous methods of predicting financial distress of industrial groups, which is used right here considering elements such as accuracy and health of model for predicting financial distress in the industry. Concerning management, time-series prediction is one of the applications of neural networks. Corporate financial trouble is typically superb in capital market liquidity and economic development. When financial distress occurs, banks generally limit bankrupt companies and credits, and in exchange for loans, they demand more exceptional pastime to compensate for their increased risk. Given the reverse impacts of financial distress on capital markets and the economy, researchers and beneficiaries have tried to create and advance various predicting models using distinct procedures to minimize its effects and incurred losses (Salehi and Pour 2016).

Academicians and practitioners have conducted intensive research regarding models for bankruptcy prediction and default events to manage credit risk. Traditional statistics techniques (e.g., logistic regression and discriminant analysis), as well as early artificial intelligence models (e.g., artificial neural networks), have evaluated bankruptcy. In the study, machine learning models (support vector machines, bagging, boosting, and random forest) were tested to forecast for bankruptcy one year before the event and compare their performance with results from the neural networks, logistic regression, and discriminant analysis data for the years 1985 to 2013 on North American firms, analyzing more than 10,000 firm-year observations. Insightful findings revealed a substantial improvement in the accuracy of the prediction using machine learning techniques.

Comparing the best models, with all predictive variables, the machine learning technique related to random forecast led to $87 \%$ accuracy, whereas logistic regression and linear discriminant analysis led to $69 \%$ and $50 \%$ accuracy, respectively, in testing the sample. We find that bagging, boosting, and random forest models outperform the other techniques and that all prediction accuracy in the testing sample improves when additional variables are included (Barboza et al. 2017).

\subsection{Kenya's Situational Context}

In Kenya, many studies have been conducted to predict bankruptcy using ratios. One of the current studies undertaken investigated the financial soundness of small and medium-sized commercial banks in Kenya over four years, 2014 to 2017, using a model known as a bankometer. The aim was to compare the financial soundness of two bank categories using data from 12 medium-sized and 16 small banks. The equity to assets ratio, capital to assets ratio, non-performing loans ratio, ratio of loans to assets, operating cost to operating income ratio, and capital adequacy ratio was used to measure the financial health of banks. One of the key findings revealed that both small and medium-sized commercial banks were financially sound during the four years of study. The study established an insignificant difference in the relationship between the two bank categories. The findings also revealed that the studied bank experienced poor performance in loans and operations, while the capital adequacy of the two banks was below the benchmark. The results of the study are essential because they can be applied in formulating policies and strategies that will help in stimulating progress in the financial 
performance of the banking sector, as well as other industries of the Kenyan economy (Ouma and Kirori 2019).

Range et al. (2018) conducted a study to establish the use of sales to total assets as one of the Z-score ratios models in bankruptcy prediction of both private and public-owned sugar companies in Kenya. The public-owned companies under investigation included Nzoia Sugar, Nyanza Sugar Company, Mumias sugar, Miwani sugar, South, Muhoroni Sugar Company, and Chemelil Sugar Company. The private companies, on the other hand, include Butali Sugar, Sukari Industries Limited, Kibos Sugar, and Allied Industries Company West Kenya Sugar. The motivation of the study emanated continued financial difficulty being observed by sugar companies in Kenya. A study sample of 12 sugar companies, both private and public-owned, were included in this study. Five-year secondary data of financial statements of the companies were used in this study. The findings revealed that the sales/total assets ratio does not significantly influence the likelihood of bankruptcy of sugar companies in Kenya.

In another study, (Kihooto et al. 2016) sought to predict for bankruptcy among companies in the commercial and services sector, listed at the Nairobi Securities Exchange (NSE). The main objective of the study was to establish if companies in that sector are prone to bankruptcy. Secondary data over five years (2009 to the year 2013) were used in this study; the Altman's Z-score model findings indicate that, on average, the companies' Z-scores lay between -1.88 and 3.5, which is an indication that the companies are relatively not in danger of bankruptcy.

Numerous firms in developing and transitional economies are in a financial distress situation, owing to a low level of debt service coverage. (Shisia et al. 2014), in their study on financial distress, argued that company distress had become a significant global issue after the 2008 global financial crisis, which resulted in increased business failure. Business failure was associated with bankruptcy as well as insolvency. The study used Altman's failure prediction model in predicting corporate financial distress in Uchumi Supermarkets in Kenya. A five-year period from 2001 to 2006 was used. The data were obtained from the Uchumi supermarket secretariat. Important predictor ratios included total assets, retained earnings, current assets and liabilities, the book value of the equity and sales, and earnings before interest and taxes. The study used a multivariate discriminant analysis (MDA) statistical technique based on the Altman failure prediction model. The model was fundamental and relevant to Uchumi supermarket as it recorded declining Z-score values, indicating the company's real experience in financial distress, backing up the reasons Uchumi supermarket was de-listed from the NSE in 2006. The study suggests to the potential investors in companies to use the Altman failure prediction model as an assessment tool for predicting for bankruptcy. Declining Z-score values depict a failing company.

\section{Data and Methodology}

Ratio analysis is essential in a 10-year trend analysis. In this study, the ratios of interest to the researcher included total asset debt ratio, current ratio, quick ratio, turnover ratio, working capital ratio, and net income to total assets ratio. ROE, ROA, and net profit margin were selected as the dependent variables denoting the financial performance of companies. The study population for this research included all the listed companies in the Nairobi securities and exchange market (NSE). Currently, there are 64 listed companies in Kenya. Included in the listed companies are also companies that were delisted at some point owing to financial distress. The study used ten years of financial statements of listed companies. The financial statements were obtained from the Capital Markets Authority as well as the Nairobi Securities. Canonical correlations were used to establish relationships among variables, while Logit analysis was used in building a model for predicting the financial distress of a company. Logistic regression was significant in this study because the outcome variables in this study were a dichotomy. The variables have a non-linear relationship, which violates one of the assumptions of linear regression. Logistic regression was also vital because it helps in predicting the probabilities of 
predictor variables influencing the dependent variable. Logit analysis was necessary for the study because it provided for probabilities of occurrence of the outcome.

The study was guided by the model below:

$$
Y i=\alpha+\beta 1 X 1+\beta 2 X 2+\mu I
$$

where,

$\mathrm{X}, \mathrm{X} 2 \ldots \mathrm{Xn}=$ the independent (explanatory) variables (asset turnover, debt to equity ratio, debtors turnover, total asset, debt ratio, current ratio, quick ratio, inventory turnover ratio, working capital ratio);

$\mathrm{Yi}=$ dependents variables (return on assets, return on equity, and net profit margin);

$\mathrm{Yi}=1$ if a company is financially distressed;

$\mathrm{Yi}=0$ if a company is not financially distressed.

The first equation based on logistic regression can be denoted as

$$
\ln \frac{P}{1-P}=\alpha+\beta 1 X 1+\beta 2 \times 2+\mu(1)
$$

Therefore, the probability of a company becoming financially distressed will be given by

$$
p=\frac{1}{1+e^{-(\alpha+\mathrm{B} 1 \mathrm{X} 1+\mathrm{B} 2 \times 2+\ldots \mathrm{BnXn})}}
$$

Values with a figure of 0.5 and above denote that the company is financially distressed, while numbers below 0.5 show that a company is not economically distressed. A value of 0 indicates an indifferent state of the company. On the other hand, negative coefficients reduce the probability of financial distress, while positive factors increase the chance of occurrence of bankruptcy prediction. The study used Statistical Package for Sosial Sciences (SPSS) software to aid in data analysis.

Table 1 below shows the contextual ratios and formula used in the study.

Table 1. Contextual ratios and formula.

\begin{tabular}{ccc}
\hline Variable & Grouping & Formula \\
\hline Inventory turnover & Activity & Cost of goods sold/Inventory \\
Asset turnover & Activity & Sales/Total assets \\
Debt equity ratio & Debt Coverage & Debt/Equity \\
Debtors turnover & Activity & Net Credit Sales/Average Accounts Receivable \\
Debt ratio & Debt coverage & Total liabilities/Equity \\
Current ratio & Liquidity & Current assets/Current liabilities \\
Quick ratio & Liquidity & (Current assets - inventory)/Current liabilities \\
Working capital ratio & Liquidity & Current assets $\div$ Current liabilities \\
\hline
\end{tabular}

\section{Results and Discussions}

\subsection{Canonical Correlation Matrix}

According to Table 2 below, Inventory Turnover, Asset Turnover, Debt-Equity Turnover, Debtors Turnover, Total Assets, Debt Ratio, Current Ratio, Quick Ratio, and Working Capital Ratios were independent variables, while return on assets and return on equity were the dependent variables. The table above shows the correlation matrix of both the independent and dependent variables. The findings revealed a positive correlation effect of Inventory Turnover (ITO), Debt-Equity Ratio (DER), Current Ratio (CR), and Working Capital Ratio (WCR) on the dependent variables. Asset Turnover (AT) and Debt Ratio (DR) have negative correlations with the dependent variable. Debtors 
Turnover (DT) has a positive association with Return on Equity (ROE) and a negative relationship with Return on Assets (ROA).

On the other hand, DR had a positive correlation with ROA and a negative relationship with ROE. ROA and ROE have been used as effective measures of financial performance. Higher levels of ROA and ROE denote excellent performance, while low rates denote possibilities of financial distress. The findings are similar to those in a study conducted by (Choi et al. 2018), who recommended ROA as a good predictor of bankruptcy prediction. Tota assets ratio had a negative influence on financial performance based on the findings of this study. The conclusions were contrary to the results from (Range et al. 2018), who established that sales to total asset ratio had no significant contribution to bankruptcy prediction.

Table 2. Canonical correlation matrix. ROE, return on equity; ROA, return on assets; ITO, Inventory Turnover; AT, Asset Turnover; DER, Debt Equity Ratio; DT, Debtors Turnover; TA, Total Assets; DR, debt ratio; CR, Current Ratio; QR, Quick Ratio; WCR, Working Capital Ratio.

\begin{tabular}{|c|c|c|c|c|c|c|c|c|c|c|c|}
\hline & ROA & ROE & ITO & AT & DER & DT & TA & DR & CR & QR & WCR \\
\hline ROA & 1.000 & & & & & & & & & & \\
\hline ROE & 0.064 & 1.000 & & & & & & & & & \\
\hline ITO & 0.462 & 0.424 & 1.000 & & & & & & & & \\
\hline AT & -0.054 & -0.082 & -0.110 & 1.000 & & & & & & & \\
\hline DER & 0.342 & 0.514 & 0.256 & 0.078 & 1.000 & & & & & & \\
\hline DT & -0.511 & 0.474 & -0.078 & 0.142 & -0.037 & 1.000 & & & & & \\
\hline TA & -0.636 & -0.520 & -0.410 & 0.017 & -0.395 & -0.004 & 1.000 & & & & \\
\hline DR & -0.259 & -0.265 & -0.346 & 0.200 & -0.393 & 0.063 & 0.490 & 1.000 & & & \\
\hline CR & 0.299 & 0.312 & 0.009 & 0.511 & 0.268 & 0.109 & -0.118 & -0.011 & 1.000 & & \\
\hline QR & 0.385 & -0.327 & -0.030 & 0.369 & -0.001 & 0.105 & -0.028 & 0.024 & 0.262 & 1.000 & \\
\hline WCR & 0.456 & 0.422 & -0.017 & -0.050 & 0.216 & -0.074 & -0.013 & 0.015 & 0.125 & -0.035 & 1.000 \\
\hline
\end{tabular}

\subsection{Collinearity Statistics of the Variables}

Based on the multicollinearity analysis shown in Table 3 below, the quick ratio was excluded from the subsequent investigation, the stepwise Logit analysis, because of its high multicollinearity. The independent variables chosen under this model included inventory turnover, asset turnover, debt-equity ratio, debtors turnover, total assets, debt ratio, current ratio, and working capital. ROE and ROA were the dependent variables of the study. Stepwise Logit analysis was conducted to evaluate the impact of a number of independent variables on the likelihood that companies will be financially distressed. Eight independent variable models were drawn to denote their relationship with the dependent variable.

Table 3. Collinearity statistics of the variables.

\begin{tabular}{ccc}
\hline Variable & Tolerance & VIF \\
\hline Inventory turnover & 0.959 & 1.043 \\
Asset turnover & 0.925 & 1.081 \\
Debt equity ratio & 0.978 & 1.022 \\
Debtors turnover & 0.958 & 1.044 \\
Total asset & 0.947 & 1.056 \\
Debt ratio & 0.917 & 1.091 \\
Current ratio & 0.932 & 1.073 \\
Quick ratio & 0.372 & 2.685 \\
Working capital ratio & 0.969 & 1.032 \\
\hline
\end{tabular}

\subsection{Test Statistics}

The final model was statistically significant, with a chi-square value of 119.969 and 3 degrees of freedom and sig value $(p<0.005)=0.000$. This indicates that the model was able to distinguish between 
financially distressed and non-financially distressed companies. Similar results were established by (Klepac and Hampel 2017), who said that being able to differentiate between economically distressed and non-financially distressed companies increases the average accurateness of the financial distress prediction. The findings are as tabulated below in Table 4.

Table 4. Test statistics.

\begin{tabular}{cc}
\hline $\mathrm{N}$ & 550 \\
\hline Chi-Square & 119.969 \\
\hline $\mathrm{df}$ & 3 \\
\hline Asymp. Sig. & 0.000 \\
\hline
\end{tabular}

\subsection{Logit Analysis}

The findings in Table 5 show eight predictor variables that contribute to the logistic analysis model. The predictors include inventory turnover, asset turnover, debt-equity ratio, debtors turnover, total asset, debt ratio, current ratio, and working capital ratio. The dependent variables for the study included ROA and ROE. Wald statistic was conducted to show the contribution of each variable to the model. The $p$-value is significant to the model in establishing the level of significance and contribution of each variable. Variables with sig-value $p<0.005$ contribute significantly to the model. Asset turnover, total assets, and working capital ratio have positive coefficients. This shows that they increase the chances of bankruptcy. They have a more significant contribution to predicting bankruptcy in companies. Higher values in the mentioned ratios can lead to financial distress in companies.

Table 5. Logit analysis results.

\begin{tabular}{ccccc}
\hline Iv & B & S.e & Wald & Sig-Value \\
\hline Inventory turnover & -0.068 & 0.178 & 5.245 & $0.000^{* * *}$ \\
Asset turnover & 2.269 & 0.935 & 7.865 & $0.006^{* * *}$ \\
Debt equity ratio & -4.987 & 1.452 & 6.458 & $0.003^{* * *}$ \\
Debtors turnover & -0.075 & 0.009 & 8.456 & $0.001^{* * *}$ \\
Total asset & 2.853 & 0.759 & 9.985 & $0.003^{* * *}$ \\
Debt ratio & -3.296 & 2.498 & 8.321 & $0.002^{* * *}$ \\
Current ratio & -0.059 & 0.085 & 6.429 & $0.033^{* *}$ \\
Working capital ratio & 0.086 & 0.026 & 6.382 & $0.010^{* *}$ \\
\hline$* * *$ statistically significant at $1 \%$ level. ${ }^{* *}$ Statistically significant at $5 \%$ level.
\end{tabular}

On the other hand, inventory turnover, debt-equity ratio, debtors turnover, debt ratio, and current ratio have negative coefficients. Negative coefficients reduce the risk of financial distress in listed companies in the Nairobi Securities and Exchange Market. Ratios are essential predictors of financial distress, as seen in a study conducted by (Geng et al. 2015), who found that return on total assets, earnings per share, the net profit margin of total assets, and cash flow per share play an essential role in the prediction of deterioration in profitability. On the other hand, (Ouma and Kirori 2019) established that the equity to assets ratio, capital to assets ratio, non-performing loans ratio, ratio of loans to assets, operating cost to operating income ratio, and capital adequacy ratio were significant predictors of the financial health of banks. Similarly, (Charalambakis and Garrett 2019) used leverage, size, profitability, retained earnings to total assets, and liquidity ratio as an export dummy variable, which proved to be essential predictors of bankruptcy prediction.

The logistic regression model can be as shown below:

$$
P=\frac{1}{1+e^{-(-0.068 \times 1+2.269 \times 2-4.987 \times 3-0.075 \times 4+2.853 \times 5-3.296 \times 6-0.059 \times 7+0.086 \times 8)}}
$$


where,

$$
\begin{aligned}
& \mathrm{X} 1=\text { Inventory turnover } \\
& \mathrm{X} 2=\text { Asset turnover } \\
& \mathrm{X} 3=\text { Debt equity ratio } \\
& \mathrm{X} 4=\text { Debtors turnover } \\
& \mathrm{X} 5=\text { Total asset } \\
& \mathrm{X} 6=\text { Debt ratio } \\
& \mathrm{X} 7=\text { Current ratio } \\
& \mathrm{X} 8=\text { Working capital ratio }
\end{aligned}
$$

Given the value of $\mathrm{X} 1-\mathrm{X} 8$, the cost of $\mathrm{B}$ can be established. A value greater than 0.5 shows the possibility of a company going into financial distress. This study, therefore, identified inventory turnover, asset turnover, debt equity ratio, debtors turnover, total asset, debt ratio, current ratio, and working capital ratio as the most significant ratios for projecting for bankruptcy. The findings show that financial ratios can be used to predict financially distressed companies in the Nairobi Securities and Exchange Market.

\subsection{Classification Table}

Table 6 below tabulates the percentage of correct classifications for the logistic model. The logistical model correctly classified $83 \%$ of overall cases, also known as the percentage accuracy in the classification, which is higher than $50 \%$. The results, therefore, showed that the Bayesian logistic model is a strict mode of correctly classifying firms as either being distressed or not.

Table 6. Classification table.

\begin{tabular}{ccccc}
\hline & & & Predict \\
\hline $\begin{array}{c}\text { Logit } \\
\text { Classification } \\
\text { Output }\end{array}$ & & Distressed & Percentage Correct \\
\hline Observed & & 0 & 1 & \\
Distressed & 0 & 51 & 9 & 82.0 \\
& 1 & 8 & 52 & 84.0 \\
Overall Percentage & & & & 83.0 \\
\hline
\end{tabular}

\section{Conclusions}

Knowledge of an upcoming bankruptcy is a crucial aspect of the decision-making process of the imperilled company itself, as well as of other institutions interacting with the company. In this paper, we propose ratio analysis as an investigative tool for establishing bankruptcy, as the financial statements of a company are readily available. This study found out that the predictor variables that can be used to predict for bankruptcy in companies in the NSE included inventory turnover, asset turnover, debt equity ratio, debtors turnover, total asset, debt ratio, current ratio, and working capital ratio as the most significant ratios. A $p$-value greater than 0.5 shows a possibility of a company going into financial distress, while smaller amounts show the absence of financial trouble in companies listed in the NSE. Using listed and delisted companies in the NSE allowed the researchers to achieve significant results. Combining several ratios was also crucial in proposing a bankruptcy forecasting model relevant to making investment decisions by performing a comparative diagnosis using several variables for predicting financial distress. This study, therefore, made the following observations based on the findings from the research.

Several studies focused on validating the Altmans model for predicting for bankruptcy rather than developing a current model that can be used in corporate as well as public companies. The study recommends that investors must apply tested bankruptcy prediction models that can help in safeguarding their interests by making prudential decisions. 
There is a need to conduct a comparative study in companies that are not listed but publish their financial statements. This will help in developing a robust model that can be used in the country when making investment decisions. For the researcher to improve on model construction, there is a need to construct an industry-based model. This will help in selecting effective models applicable in a sector. The conflict of earnings management poses a significant threat in the construction of useful, accurate, and reliable models in Kenya. Therefore, there is a need for research on audited financial data to reduce the risk associated with earnings management in making investment decisions.

Author Contributions: Conceptualization and Original Draft Preparation, D.O.; Literature Review, D.O., R.N., and P.G.; Methodology, Z.Z.; Analysis, D.O.; Findings, D.O. and R.N.; Proofreading, P.G.; Supervision, Z.Z. All authors have read and agreed to the published version of the manuscript.

Funding: This research received no external funding.

Acknowledgments: I would like to acknowledge the Tempus Public Foundation for awarding me a PhD scholarship to study in Hungary. Special thanks to Lecturers and staff at the Szent Istvan University.

Conflicts of Interest: The authors declare no conflict of interest.

\section{References}

Agrawal, Le, and Yogesh Maheshwari. 2019. Efficacy of industry factors for corporate default prediction. IIMB Management Review 31: 71-77. [CrossRef]

Alifiah, Mohd Norfian. 2014. Prediction of Financial Distress Companies in the Trading and Services Sector in Malaysia Using Macroeconomic Variables. Procedia-Social and Behavioral Sciences 129: 90-98. [CrossRef]

Barboza, Flavio, Herbert Kimura, and Edward Altman. 2017. Machine learning models and bankruptcy prediction. Expert Systems with Applications 83: 405-17. [CrossRef]

Ben Jabeur, Sami. 2017. Bankruptcy prediction using Partial Least Squares Logistic Regression. Journal of Retailing and Consumer Services 36: 197-202. [CrossRef]

Boratyńska, Katarzyna, and Emilia Grzegorzewska. 2018. Bankruptcy prediction in the agribusiness sector: Lessons from quantitative and qualitative approaches. Journal of Business Research 89: 175-81. [CrossRef]

Charalambakis, Evangelos, and Ian Garrett. 2019. On corporate financial distress prediction: What can we learn from private firms in a developing economy? Evidence from Greece. Review of Quantitative Finance and Accounting 52: 467-91. [CrossRef]

Choi, Hyunchul, Hyojoo Son, and Changwan Kim. 2018. Predicting financial distress of contractors in the construction industry using ensemble learning. Expert Systems with Applications 110: 1-10. [CrossRef]

Chou, Chih Hsun, Su Chen Hsieh, and Chui Jie Qiu. 2017. Hybrid genetic algorithm and fuzzy clustering for bankruptcy prediction. Applied Soft Computing Journal 56: 298-316. [CrossRef]

Cleofas-Sánchez, Laura, Vicente García, Ai Marqués, and Jose Salvador Sánchez. 2016. Financial distress prediction using the hybrid associative memory with translation. Applied Soft Computing Journal 44: 144-52. [CrossRef]

García, Vicente, Ai Marqués, Jose Salvador Sánchez, and Humberto Jesus Ochoa-Domínguez. 2019. DissimilarityBased Linear Models for Corporate Bankruptcy Prediction. Computational Economics 53: 1019-31. [CrossRef]

Geng, Ruibin, Indranil Bose, and Xi Chen. 2015. Prediction of financial distress: An empirical study of listed Chinese companies using data mining. European Journal of Operational Research 241: 236-47. [CrossRef]

Gepp, Adrian, and Kuldeep Kumar. 2015. Predicting Financial Distress: A Comparison of Survival Analysis and Decision Tree Techniques. Procedia Computer Science 54: 396-404. [CrossRef]

Hosaka, Tadaaki. 2019. Bankruptcy prediction using imaged financial ratios and convolutional neural networks. Expert Systems with Applications 117: 287-99. [CrossRef]

Jones, Stewart. 2017. Corporate bankruptcy prediction: A high dimensional analysis. Review of Accounting Studies 22: 1366-422. [CrossRef]

Kihooto, Elijah, Job Omagwa, Muturi Wachira, and Emojong Ronald. 2016. Financial Distress in Commercial and Services Companies Listed at Nairobi Securities Exchange, Kenya. European Journal of Business and Management Www.Iiste.Org ISSN 8: 86-89.

Klepac, Vaclav, and David Hampel. 2017. Predicting financial distress of agriculture companies in the EU. Agricultural Economics (Czech Republic) 63: 347-55. [CrossRef] 
Laitinen, Erkki, and Arto Suvas. 2016. Financial distress prediction in an international context: Moderating effects of Hofstede's original cultural dimensions. Journal of Behavioral and Experimental Finance 9: 98-118. [CrossRef]

Li, Zhiyong, Jonathan Crook, and Galina Andreeva. 2017. Dynamic prediction of financial distress using Malmquist DEA. Expert Systems with Applications 80: 94-106. [CrossRef]

Lin, Cmich, and Xiaobo Dong. 2018. Corporate social responsibility engagement of financially distressed firms and their bankruptcy likelihood. Advances in Accounting 43: 32-45. [CrossRef]

López-Gutiérrez, Carlos, Sergio Sanfilippo-Azofra, and Bego Torre-Olmo. 2015. Investment decisions of companies in financial distress. BRQ Business Research Quarterly 18: 174-87. [CrossRef]

Lukason, Oliver, and Richard Hoffman. 2014. Firm Bankruptcy Probability and Causes: An Integrated Study. International Journal of Business and Management 9: 80-91. [CrossRef]

Mai, Feng, Shaonan Tian, Chihoon Lee, and Ling Ma. 2019. Deep learning models for bankruptcy prediction using textual disclosures. European Journal of Operational Research 274: 743-58. [CrossRef]

Mselmi, Nada, Amine Lahiani, and Taher Hamza. 2017. Financial distress prediction: The case of French small and medium-sized firms. International Review of Financial Analysis 50: 67-80. [CrossRef]

Ouma, Moses, and Gabriel Kirori. 2019. Evaluating the Financial Soundness of Small and Medium-Sized Commercial Banks in Kenya: An Application of the Bankometer Model. International Journal of Economics and Finance 11: 93. [CrossRef]

Range, Mwita Maurice, Agnes Njeru, and Gichuhi Waititu. 2018. Using Altman's Z score (Sales/Total Assets) Ratio Model in Assessing Likelihood of Bankruptcy for Sugar Companies in Kenya. International Journal of Academic Research in Business and Social Sciences 8: 683-703. [CrossRef]

Salehi, Mahdi, and Mojdeh Davoudi Pour. 2016. Bankruptcy prediction of listed companies in Tehran Stock Exchange. Dynamic Factor Models 35: 317-60. [CrossRef]

Shisia, Adam, William Sang, Serah Waitindi, and Walter Bichanga Okibo. 2014. An In-Depth Analysis of the Altman's Failure Prediction Model on Corporate Financial Distress in Uchumi Supermarket in Kenya. European Journal of Business and Management 6: 27-42.

Shrivastava, Arvind, Kuldeep Kumar, and Nitin Kumar. 2018. Business distress prediction using a Bayesian logistic model for Indian firms. Risks 6: 113. [CrossRef]

Šlefendorfas, Gediminas. 2016. Bankruptcy prediction model for private limited companies of Lithuania. Ekonomika 95: 134. [CrossRef]

Sun, Jie, Hamido Fujita, Peng Chen, and Hui Li. 2017. Dynamic financial distress prediction with concept drift based on time weighting combined with Adaboost support vector machine ensemble. Knowledge-Based Systems 120: 4-14. [CrossRef]

Svabova, Lucia, Marek Durica, and Ivana Podhorska. 2018. Prediction of Default of Small Companies in the Slovak Republic. Economics and Culture 15: 88-95. [CrossRef]

Tobback, Ellen, Tony Bellotti, Julie Moeyersoms, Marija Stankova, and David Martens. 2017. Bankruptcy prediction for SMEs using relational data. Decision Support Systems 102: 69-81. [CrossRef]

Zhang, Yudong, Shuihua Wang, and Genli Ji. 2013. A rule-based model for bankruptcy prediction based on an improved genetic ant colony algorithm. Mathematical Problems in Engineering 2013. [CrossRef]

Zięba, Maciej, Sebastian Tomczak, and Jakub Tomczak. 2016. Ensemble boosted trees with synthetic features generation in application to bankruptcy prediction. Expert Systems with Applications 58: 93-101. [CrossRef]

(C) 2020 by the authors. Licensee MDPI, Basel, Switzerland. This article is an open access article distributed under the terms and conditions of the Creative Commons Attribution (CC BY) license (http://creativecommons.org/licenses/by/4.0/). 